\title{
The Effect of Online Problem Posing on Students' Problem-Solving Abilitiy in Mathematics
}

I Made Suarsana

M.Si., Ganesha University of Education, Indonesia, suarsana1983@gmail.com

\section{Ida Ayu Putu Diah Lestari}

Ganesha Universitiy of Education, Indonesia, diahlestari774@gmail.com

Ni Made Sri Mertasari

Dr., Ganesha University of Education, Indonesia, srimertasarinimade@yahoo.co.id problem-solving ability in mathematics. The study followed a quasi-experimental research with post-test that only controlled group design. The population was all of the 11th grade students in science classes of SMA Negeri 4 Singaraja in the academic year 2017/2018. A total of 119 students were sampled using cluster random sampling techinique that were divided into 39 in experimental class, 40 in comparative class and 40 conventional class. The instrument used in this study was a mathematics problem-solving ability essay test. The data were analyzed using One Way ANOVA and Sceffe test. The result showed that there was a difference in terms of problem-solving ability in mathematics among the students who used online problem posing, problem posing and conventional learning. The result of Scheffe test showed that students' problem-solving abilitiy in mathematics that used online problem posing was better. The study revealed that online problem posing had a significant effect on students' problem-solving abilitiy in mathematics, which are better than problem posing or conventional learning.

Keywords: edmodo, mathematics, online problem posing, problem posing, problemsolving ability

\section{INTRODUCTION}

Students normally learn from questions. A question in mathematics can be defined as a problem if it is not a routine question. Non-routine question is a question in which the solution procedure has not been known yet by students, therefore they have the interest to solve it. The problem posed is required to enable them to possess a problem-solving ability. According to Polya (1954), students can solve a problem if they can complete

Citation: Suarsana, I M., Lestari, I. A. P. D., \& Mertasari, N. M. S. (2019). The Effect of Online Problem Posing on Students' Problem-Solving Abilitiy in Mathematics. International Journal of Instruction, 12(1), 809-820. https://doi.org/10.29333/iji.2019.12152a 
four steps as follows: (1) understand the problem, (2) devise a plan, (3) carry out the plan, (4) looking back. The importance of problem-solving ability is confirmed by NCTM (2010) that in mathematics learning, problem-solving is an integral part of mathematics learning. Thus, the existence of problem solving plays a fundamental place in mathematics learning. In line with the level of cognitive competence for secondary school level, the students must achieve the competency standard of graduates stipulated by the central government of Indonesia Permendikbud No. 21 Tahun 2016, in which each student is expected to be able to apply their knowledge to solve the problem, whether in mathematics learning or real life. Students get an experience from the problem-solving process. This experience will improve their thinking ability to become logical, analytical, critical, and creative when facing the problem.

The Programme for International Student Assessment (PISA) is a worldwide study by the Organisation for Economic Co-operation and Development (OECD) in member and non-member nations intended to evaluate educational systems by measuring 15 -year-old school pupils' scholastic performance on mathematics, science, and reading. The result of survey conducted by PISA (2015) showed that in mathematics, Indonesia was in the 63rd rank from 70 countries with the average score of 386, while the average score of PISA International is 500 (OECD, 2016). One of the factors causing the low average score of mathematics in PISA test is students' reasoning and creativity in solving real context problem that which is still low and students are not familiar with the real content model. The most influential factor is the students are not accustomed to use the process of problem-solving correctly according to Polya (Nisa, 2017). The national exam results for senior high schools in Indonesia showed that the average grade from 2015 until 2017 was decreasing, this also happened in Buleleng Regency. The score of mathematics national exam for senior high school in 2017 for in terms of cognitive domain was determined from three parts: (1) knowledge and understanding, (2) application, and (3) reasoning. One of the factors causing the low average score of the national exam is the lack ability to solve the application problems that require a problem-solving ability. In regard to that problem, an innovative learning model is needed to allow the students explaining their ideas on mathematics in a stress-free atmosphere so they can improve their problem-solving ability.

Problem-solving ability on mathematics was related with problem-posing ability. Silver and Cai (1996) explained that problem-posing has positively correlated with problemsolving ability. In line with this, English (1997) explained that raising a problem is the first step, next the problem needs to be understood. Once it is understanble, the next step is to solve the problem. A Meta-synthesize research conducted by Rosli, Mary and Robert (2014) found on the effectiveness of problem posing which showed that problem-posing activities can have broad potential benefits on students' mathematical learning competence, namely problem solving skills.

Problem posing is a learning model that students are posing the problem based on the certain situation then solve it (Zarkasyi, 2015). In this learning model, the problem is not given by the teacher but the students raise their own problem, the teacher only gives the situation and the students formulate the problem based on that situation. There are three 
types of problem posing learning model, one of them is problem posing with postsolution posing. Problem posing with post-solution posing is a learning model in which the students modify the objective or situation from the problem that has been solved to make the new problems. Problem posing activity can improve students' creative thinking ability. This is in line with the result of a study conducted by Nuha, Waluya and Junaedi (2017) which showed that problem posing learning model with lesson study approach that can improve students' creative thinking on mathematics. Creative thinking ability can help the student understand or devise a plan when they solve the problem, so they can solve the problem better. This had an impact on students' problem-solving abilitiy in mathematics.

Living in the millennial generation makes all aspects of our life close to technology. The example in education, computer-based learning communication has been very popular by utilizing various online learning media, one of them is Edmodo. Edmodo is a social network-based education application that looks like Facebook. Edmodo has some advantages for the teacher, they can get the authority to provide warnings, assignments, assessments, polls, and agendas for their students using Edmodo. Beside that, there are facilities such as discussion groups that allow students to ask something about the lesson that are not understood when learning in the classroom, whenever and wherever they are provided there is free access learning on the internet.

Online problem posing in this study is problem posing using the type of post solution posing assisted by Edmodo. Learning activity in the class is conducted according to the steps of problem posing learning model and using Edmodo to assist in giving and collecting assignment. At the time of classroom learning, students formulate the problem in which they modify the objective or situation of the previous problem that has given by the teacher using lottery. Teacher give the paper containing number 1 to 4 then students take it using lottery. The students had to modifie based on the way that they got from that number, which are number 1 was modifie the problem by change information or data of previous problem, number 2 was add information or data on previous problem, number 3 was change the value of data, but preserve the situation or condition of previous problem, and number 4 was change the situation or condition of previous problem but preserve the data or information. After the students conducting the new problem based on that way, then they solve it with their group. The formulation of the problem can help the students understand the problem. A study conducted by Lestari (2015), revealed that, the problem posing has a good effect on students' mathematical concept. Then, the understanding concept can help the students understand the problem better.

Using this type of post solution posing, the students should formulate a variety problems compared to previous problem solving activity. This helps students practice in devising the right plan to solve the problem. In this step, the students should search relevant sources that can be used as references to solve the problem. This activity can improve students' participation in the classroom. This is in line with the study conducted by Susanti (2012) that learning mathematics with problem posing learning model based on character education could improve students' activity in the class. Concept understanding 
and learning activity could improve mathematical reasoning ability. This is in accordance with the study conducted by Falach (2016) which proved that the problem posing is more effective than problem-solving learning model which is viewed from the students' reasoning ability in mathematics. A good reasoning ability can help the students make conclusion easier from some facts that they have known, so they can solve the formulated problem easier. When the students have successfully solved the problem, they can switch the problem with another group and solve the problem that they gained from another group. Because the problem formulated by each group is different, then the students must understand the problem first. After the students solve the problem formulated by their group and another group, the teacher selects the representative group to present the answer in front of the class. At that time, the groups formulate their problem and can review on the answer that they have been created. Looking back is the last steps in mathematical problem-solving. In this step, students reviewed the problem or solution that the have been created based on another answer from another group and teacher's summary.

After the classroom activity, the teacher uploads individual assignments on Edmodo through the assignment feature. The assignment is formulated post solution posing problem according to the examples that given by teacher related to the materials that they had already studied in the class. Using Edmodo makes the students able to collect the assignments whenever and wherever it is possible within a due time and discuss more outside the classroom with friends or teachers. In addition, students can also directly get feedback from teachers about the assignment which they submitted on Edmodo, so they can correct their mistakes early which has an impact to improving their problem-solving activity. This is in support of a study by Putra (2016) that the use of Edmodo had a good effect of students' learning achievement on mathematics. Based on the above description, the researcher is interested conduct a study about the effect of online problem posing on students' problem-solving ability in mathematics.

\section{RESEARCH QUESTIONS}

The research questions are as follows:

1. Whether any differences in the students' problem-solving abilitiy between the students who use online problem posing, problem posing, and conventional learning?

2. Whether the students' mathematical problem-solving abilitiy who use online problem posing is better than those who use problem posing and conventional learning?

\section{LITERATURE REVIEW}

\section{Problem Solving}

The question in mathematics can be defined as a problem if it is not a routine question. The non-routine question is a question in which the solution procedure has not been known yet by students, so they have the interest to solve it. According to Hudojo (2005), the specifications of the problems for a student are: (1) questions posed by the student should be understood by the students and become a challenge for the students to be able to solve them, (2) questions posed by the students cannot be answered by routine 
procedures that have been known and therefore requires them to have the problemsolving ability. Suherman (2003) explained that the main thing in solving the problem is the sense of interest in facing the challenge and the desires to solve that challenge.

According to Polya (1954), there are four main steps that must be followed to solve mathematics problem, they are: (1) understand the problem: understand what to look for, what are known, what conditions can be enough to look for the unknown, create an image or graph, (2) devise a plan: there is more than one way to solve the problem, but it takes skill to choose the best strategy. In this case, the plan or design is made to solve the problem, (3) carry out the plan; in this step, solving the problem according to the plan that has been devised in the second step. This step is easier than the second step, it just takes precision and skill in solving the problem so that no errors occur. Checking every step is necessary, (4) looking back: in this step, students are checking the result that they have done.

\section{Online Problem Posing}

Problem posing is one of the learning models that can improve the creative thinking ability on mathematical reasoning. According to Zarkasyi (2015), problem posing is a learning model in which the students pose the problems based on certain situations given by teacher. Silver (1994) explained that there are three types of problem posing, one of them is post-solution posing. Post solution posing is a learning model in which the teacher gives examples of the problem, students modify the objectives or conditions of the problem that has been solved to formulate a new problem. This learning model focuses on to modify the previous problem into a more challenging problems. Several ways can be used to modify the problems, they are: (1) change the information or data on the previous problem, (2) add information or data on the previous problem, (3) change the value of data, but still preserve the condition or situation of the previous problem, (4) change the situation or condition of the previous problem, but still preserve the data or information on the previous problem. Silver (1996) recommends learning with problem posing it can encourage creative activity and improve mathematical ability especially problem-solving ability.

Online problem posing in this study was problem posing which the type is post solution posing assisted by Edmodo. Learning activity in the class is conducted according to the steps of problem posing learning model and using Edmodo to assist in giving and collecting assignment, besides discussing with friends or teacher outside the class. The results of the study that was conducted by Dwi Sulisworo (2018) showed that from several online applications that can support learning activities, Edmodo was an application that tended to be used perceively by students, so this app needed to be pursued with various learning strategies. The advantage of using this app was students can collect assignments whenever and wherever as long as in due time, students also can discuss outside the class with their friends or teacher, besides the students could also directly given the feedback from the teacher about the assignment that they have done on Edmodo. This is in line with Ainiyah (2015) that explained the used of Edmodo can make learning activities were not depended with place and time and makes the class 
more dynamic because it allowed the interaction of teachers and students and students with students in terms of lessons and assignments.

In the classroom using online problem posing, students formulate the problem which the type is post-solution posing by modify the objective or condition of the previous problem according to the method gained from the lottery, then they solve it with their group. Students do not only solve the problem that they have been created, but they also switch the problem with another group. The problems was gained from other groups are also resolved. After classroom learning activity, the teacher uploads individual assignments on Edmodo through the assignment features. The assignment is formulated post solution posing according to the examples that given by the teacher related to the materials already studied in the class. Using Edmodo makes the students can collect assignments whenever and wherever provided within a due time, it can discuss more outside the class with their friends or teachers, besides thatm the students can also directly get feedback from the teachers about the assignment that they have been done in Edmodo so they can correct their mistakes early which had an impact on students' mathematical problem-solving ability.

\section{METHOD}

\section{Research Design}

This study was a quasi experimental research using post-test only control group design. Post-test only controlled group design because the population of this study was all of the $11^{\text {th }}$ students in science classes of SMA Negeri 4 Singaraja that all of them were 273 students that were spread away into 7 classes randomly, there were not honor class and non honor class. A total of 119 students were sampled using cluster random sampling techinique, then their equality was tested to establish equal categories. Three classes were categories equal, then it was randomized again to determine experimental class, comparative class, and control class. Experimental class $(n=39)$ was conducted by online problem posing learning, comparative class $(n=40)$ was conducted by problem posing learning, and control class $(n=40)$ was conducted by conventional learning.

Table 1

Syntaxes of online problem posing learning, problem posing learning, and conventional learning.

\begin{tabular}{|c|c|c|}
\hline Online problem posing learning & Problem posing learning & Conventional learning \\
\hline $\begin{array}{l}\text { 1. Teacher introduces the new } \\
\text { materials }\end{array}$ & $\begin{array}{l}\text { 1. Teacher introduces the } \\
\text { new materials }\end{array}$ & $\begin{array}{l}\text { 1. Teacher introduces the } \\
\text { new materials. }\end{array}$ \\
\hline $\begin{array}{l}\text { 2. Teacher gives information to } \\
\text { formulate post solution posing } \\
\text { problem. }\end{array}$ & $\begin{array}{l}\text { 2. Teacher gives information } \\
\text { to formulate post solution } \\
\text { posing problem. }\end{array}$ & $\begin{array}{l}\text { Students ask the teacher } \\
\text { if they do not understand } \\
\text { about the explanation. }\end{array}$ \\
\hline $\begin{array}{l}\text { 3. Grouping the students of } 4-5 \\
\text { persons. }\end{array}$ & $\begin{array}{l}\text { 3. Grouping the students of } \\
4-5 \text { persons. }\end{array}$ & Pairing the students with \\
\hline $\begin{array}{l}\text { 4. Raffling the ways to formulate post } \\
\text { solution problem by lottery. }\end{array}$ & $\begin{array}{l}\text { 4. Raffling the ways to } \\
\text { formulate post solution }\end{array}$ & $\begin{array}{l}\text { their seatmate } \\
\text { Students discuss with }\end{array}$ \\
\hline Formulating the problem & problem by lottery. & their seatmate to solve \\
\hline $\begin{array}{l}\text { Students with their group solve the } \\
\text { problem in a worksheet to find the } \\
\text { concept of the materials, }\end{array}$ & $\begin{array}{l}\text { 5. Formulating the problem } \\
\text { Students with their group } \\
\text { solve the problem in a }\end{array}$ & $\begin{array}{l}\text { the problems in } \\
\text { worksheet. } \\
\text { Teacher selects the }\end{array}$ \\
\hline
\end{tabular}




\begin{tabular}{|c|c|c|}
\hline Online problem posing learning & Problem posing learning & Conventional learning \\
\hline $\begin{array}{l}\text { understanding the example of the } \\
\text { problem that given in worksheet to } \\
\text { formulate one or two post solution } \\
\text { problems according to the ways that } \\
\text { they gained from lottery and then } \\
\text { solve it. } \\
\text { 6. Switching the problems } \\
\text { Students switch the problems that } \\
\text { they have been formulated with } \\
\text { other groups then solve it. } \\
\text { The selected groups presents their } \\
\text { own problems and the gained } \\
\text { problems from another group } \\
\text { Teacher uploads individual } \\
\text { assignment on Edmodo } \\
\text { Students formulate a post solution } \\
\text { posing problem by choosing one of } \\
\text { the existing ways and then collect it } \\
\text { on Edmodo. } \\
\text { Teacher gives immediate feedback } \\
\text { After the students collect the } \\
\text { assignment, teacher give immediate } \\
\text { feedback, then students correct it } \\
\text { and collect the revision. Beside that, } \\
\text { students can discuss about the } \\
\text { assignment or materials on Edmodo } \\
\text { outside classroom learning } \\
\text { whenever and wherever. }\end{array}$ & $\begin{array}{l}\text { worksheet to find the } \\
\text { concepts of the materials, } \\
\text { understanding the example } \\
\text { of the problem that given } \\
\text { in worksheet to formulate } \\
\text { one or two post solution } \\
\text { problems according to the } \\
\text { ways that they gained } \\
\text { from lottery and then solve } \\
\text { it. } \\
\text { Switching the problems } \\
\text { Students switch the } \\
\text { problems that they have } \\
\text { been formulated with } \\
\text { other groups then solve it. } \\
\text { The selected groups } \\
\text { presented their own } \\
\text { problems and the gained } \\
\text { problems from another } \\
\text { group. } \\
\text { Teacher gives individual } \\
\text { assignment. } \\
\text { Students formulate a post } \\
\text { solution posing problem } \\
\text { by choosing one of the } \\
\text { existing ways and collect } \\
\text { it in next meeting. }\end{array}$ & $\begin{array}{l}\text { groups to share their } \\
\text { answer in front of the } \\
\text { class } \\
\text { 4. Teacher evaluates the } \\
\text { lesson with the students. } \\
\text { 5. Teacher gives individual } \\
\text { assignment } \\
\text { Students answer the } \\
\text { problem given by the } \\
\text { teacher. }\end{array}$ \\
\hline
\end{tabular}

\section{Data Collection and Analysis}

Mathematical problem-solving ability assessed through essay test and then students' answers were assessed through an analytic rubric. Instrument preparation was done by expert judgments' test by two expert lecturers in mathematics education. The results showed that the instrument had a content validity of 1 , in other words all items used were relevant in terms of experts' judgment view. The instrument was tested in XI IPA SMA Negeri 2 Singaraja students to gain the construct validity and test reliability. The construct validity test using product moment correlation coefficient showed that from eight questions tested, question number 1 was invalid while the others were valid. Furthermore, valid items were tested for reliability using Alpha Cronbach formula. The result showed that the degree of reliability was 0.62 which indicates that the test belongs to the category of high reliability.

Student's mathematical problem-solving abilities was measured by a post-test at the end of the lesson. The data were analyzed using one-way ANOVA test to know if there were differences in problem-solving abilitiy among the students of the experimental class, comparative class, and control class. If there was a significant difference, then followed by Scheffe test to know which class was better. The Scheffe test was used because the numbers of students in each class was not the same. 


\section{FINDINGS}

According to Polya (1954), there are four main steps that must be done in solving mathematics problems such as understand the problem, devise a plan, carry out the plan, and look back. In this study, the maximum total score for each step was 3, 3, 4, and the last step was not scored. After the result of the post-test was analyzed quantitatively, the average score of each step for the three sample classes as shown in Table 2 below.

Table 2

Summary of the scores of problem-solving ability test.

\begin{tabular}{lllll}
\hline \multirow{2}{*}{ Number } & \multirow{2}{*}{ Steps } & Class samples & & \\
\cline { 3 - 5 } & & Experimental & Comparative & Control \\
\hline 1. & Understand the problem & 2,76 & 2,6 & 2,29 \\
2. & Devise a plan & 2,19 & 1,7 & 1,4 \\
3. & Carry out the plan & 2,94 & 2,9 & 2,64 \\
\hline
\end{tabular}

The data in Table 2 shows that from the step of understand the problem has seen there is a difference in mathematical problem-solving ability between the three sample classes and students' problem-solving ability in the experimental class tends to be better than the other classes. Furthermore, the hypotheses test was conducted in order to verify this findings.

The students' mathematical problem-solving abilitiy obtained from the post-test results for the three sample classes are shown in table 3 below.

Table 3

Summary of data analysis result of students' problem-solving abilities.

\begin{tabular}{lllll}
\hline \multirow{2}{*}{ Number } & \multirow{2}{*}{ Variables } & Class samples & & \\
\cline { 3 - 5 } & & Experimental & Comparative & Control \\
\hline 1. & Number of students & 39 & 40 & 40 \\
2. & Average grade & 78,36 & 71,55 & 63,4 \\
3. & Variance & 92,82 & 95,43 & 165,99 \\
\hline
\end{tabular}

The data in table 3 shows that the average grade of problem-solving abilities on mathematics between students that used online posing problem better than other class, followed by students that used the problem posing and the last was the students who follow the conventional learning.

The prerequisite test was conducted before the hypothesis test. The prerequisite tests are normality and homogeneity test. Normality test with Liliefors Test at 5\% significance level showed that the data distribution of students' mathematical problem-solving ability on the three samples classes was a normal distribution. Then for the homogeneity test of variance with Levene test, it was shown that the value of $\mathrm{W}=1.681$ and Ftable $=3.07$. Since the value of $\mathrm{W}$ was less than Ftable it could be concluded that the data distribution of the three sample classes had a homogeneous variance.

The result of normality test and homogeneity test revealed that data from the experimental class, comparative class, and control class were normal distribution and 
had homogeneous variance. Therefore, the first hypothesis testing can be conducted by using one-way ANOVA test, to find out whether there are differences in mathematical problem-solving ability among the students that used online problem posing, the students that used problem posing and the students that used conventional learning. The summary of test results can be seen in Table 4.

Table 4

The summary of one-way ANOVA test.

\begin{tabular}{lcccc}
\hline & Sum of squares & Df & Mean square & F \\
\hline Between groups & 4434,3155 & 2 & 2217,158 & 18,8494 \\
Within groups & 13644,4744 & 116 & 117,6248 & \\
Total & 18078,7899 & 118 & & \\
\hline
\end{tabular}

The result of one-way ANOVA test showed that $\mathrm{F}=18.8494$. Then Ftable value at the 0.05 significance level with df numerator $=2$ and df denominator $=116$ was 3.07 . When compared, the F value was higher than Ftable. It means that there were differences in the mathematical problem solving ability among students who used online problem posing, students who used problem posing, and students who followed conventional learning. Then Scheffe Test was also conducted to determine which class was better.

The results of the second hypothesis tested by using Scheffe test showed that Fscheffe value $=11.294$. Then Ftable value at the 0.05 significance level with df numerator $=2$ and $\mathrm{df}$ denominator $=116$ was 3.07. Thus can be calculated $\mathrm{F}^{\prime}=(\mathrm{k}-1)$ Ftable $=(3-1) \mathrm{x}$ $3.07=6.14$. When compared, the value of Fscheffe was more than F'. It means that mathematical problem-solving ability of students who used problem posing was better than students who followed conventional learning.

The result of the third hypothesis tested using Scheffe test showed that Fscheffe value = 7,7856. Then Ftable value at the 0.05 significance level with $\mathrm{df}$ numerator $=2$ and $\mathrm{df}$ denominator $=116$ is 3.07. Thus can be calculated $F^{\prime}=(k-1)$ Ftable $=(3-1) \times 3.07=$ 6.14. When compared, the value of Fscheffe was more than F'. It means that mathematical problem-solving ability of students who used problem posing was better than students who used problem posing.

The result of the fourth hypothesis tested by using Scheffe test showed that Fscheffe value $=37,5718$. Then Ftable value at the 0.05 significance level with df numerator $=2$ and df denominator $=116$ is 3.07. Thus it can be calculated $F^{\prime}=(k-1)$ Ftable $=(3-1) x$ $3.07=6.14$. When compared, the value of Fscheffe was more than $\mathrm{F}$ '. It means the mathematical problem-solving ability of students who used online problem posing was better than students who followed conventional learning.

\section{DISCUSSION}

The students in comparative class used problem posing learning model whereas the students in control class used the conventional learning. Scheffe test showed that mathematical problem-solving ability of students who used problem posing learning model were better than those students who used conventional learning. The reason was that students in the comparative class were able to understand the problem well than 
students in control class. In line with the results of the quantitative analysis in Table 2 which shows that the average score about understands the problem step for the comparative class was 2.6 while for the control class was 2.29. The students in the comparative class were able to understand the problem better. During at the time of learning in their class they were faced with the formulation of the problem which the type was post solution posing. Students modified the objective and condition of the problem that were done to formulate new problems and then solve them. This is in line with the statement of English (1997) which stated that formulating the problem means the first step in problem-solving which is understanding the problem has been passed. It means, if students can formulating the new problem by modified initial problem, so they were understanding the problem well.

The average score for the second step, devise a plan showed that, there was a difference between comparative class and control class, the score was 1.7 for the comparative class and 1.4 for the control class. It was indicated that the ability to devise a plan for students in the comparative class was better than that of the control class. This is because the learning activities that were conducted in the comparative class were not only formulating the problem but also solve them. Students formulate new problems by modifying the objective or condition of the previous problems according to the way they were gained during the lottery, so the students discussed with their group to determine which the right plan to solve the problems was. Beside that, the students also switched the problems that they have been formulated with other groups then solve the problem that obtained from other group. Because each group made different problems, the steps of devising a plan were also different. At this stage, students had also practiced their ability to determine the right plan. The right planning can guide the students solve the problems in amore structured way, which implies to better students' problem-solving in mathematics.

The scheffe test results also showed that mathematical problem-solving ability of students who used online problem posing was better than students who used problem posing. Learning activities that were conducted in the experimental class were divided into two: inside the class activities and outside the class activities (after the classroom learning) whereas in the comparative class the overall of learning activities took place in the classroom. In general, the learning activities in the classroom that was conducted in the experimental and comparative classes is almost the same, the difference in the last step was that the teacher assigned individual homework to the students. In the experimental class, the collection of individual assignment was done by Edmodo after classroom learning activities.

Online discussions with teachers or other students related to the lessons or assignments made the students tended to be more flexible and courageous to ask questions or explain their ideas, it showed when the teacher gives feedback related to the assignment that they have been done and then students' comments, either through asking or reiterating the purpose of the answer that they have made. This activity had a positive effect on his ability to express their ideas or words when creating the plan to solve the problems. This is in line with the data in Table 2 which showed that in the devising a plan step of the 
problem solving, the average score of the experiment class was 2.11 while in the comparative class was 1.7 .

\section{CONCLUSION}

Based on the result of the research, it can be concluded that learning activities in online problem posing class have an effect for mathematical problem-solving ability which is better than the learning activities that were conducted in problem posing class or conventional class. This is evidenced by the facts that (1) there were differences in the mathematical problem solving ability between the students who used online problem posing, students who used problem posing and students who used conventional learning; (2) mathematical problem-solving ability of the students who used problem posing learning model was better than students who used conventional learning; (3) mathematical problem-solving ability of students who used online problem posing was better than students who followed the problem posing learning model; (4) mathematical problem-solving ability of the students who used online problem posing was better than students who followed conventional learning. Learning activities that conducted by problem posing learning model whics is the type is post-solution posing and assited with Edmodo to give the assignment, allowed students or teacher discussing out of the class, so that can improve students' mathematical problem solving ability which is provided students to more better in understans the problem, devise a plan and carry out the problem. It is expected to educational practitioners especially those involved in learning mathematics to use online problem posing as one of the innovative teaching to students in senior high school, as well as in junior or elementary school, in order to provide students more opportunity in experiencing mathematical problem solving ability, which can help students more understand the problem, devise a right plan so they can carry out the plan well. But, it also advisable to conduct this similar research on Online Problem Posing using larger samples and on broader materials.

\section{REFERENCES}

Ainiyah, S. (2015). Penggunaan Edmodo sebagai Media Pembelajaran E-Learning pada Mata Pelajaran Otomatisasi Perkantoran di SMKN 1 Surabaya. Jurnal Mahasiswa Unnesa, 3(3), 1-13.

English, L. D. (1997). Promoting a Problem Posing Classroom. Teaching Children Mathematics, 4, 172-180.

Falach, H. N., (2016). Perbandingan Keefektifan Pendekatan Problem Solving dan Problem Posing dalam Pembelajaran Matematika pada Siswa SMP. PHYTAGORAS: Jurnal Pendidikan Matematika, 11(2), 136-148.

Hudojo, H. (2005). Common Textbook: Pengembangan Kurikulum dan Pembelajaran Matematika. Malang: IMSTEP.

Lestari, H.; Bharata, H.; Noer, S.H. (2015). Pengaruh Pendekatan Problem Posing terhadap Kemampuan Pemahaman Konsep Matematis Siswa. Jurnal Pendidikan Matematika UNILA, 3(5). 
Lokadata. (2017). Nilai Rata-rata Ujian Nasional Matematika Tingkat SMA. Retrived 29 November, 2017 from https://lokadata.beritagar.id/chart/preview/nilai-rata-rataujian-nasional-matematika-tingkat-sma-1509004681

NCTM. (2010). Why is Teaching with Problem Solving Important to Student Learning?

$\begin{array}{llll}\text { Retrived } & 20 & \text { November, } & 2017\end{array}$
https://www.nctm.org/uploadedFiles/Research_and_Advocacy/research_brief_and_clips /Research_brief_14_-_Problem_Solving.pdf

Nisa, M. K. (2017). Analisis Kesalahan Siswa Kelas VII dalam Menyelesaikan Maemecahkan Soal Matematika Model PISA Konten Quantity. Seminar Nasional Pendidikan Matematika. Surakarta.

Nuha, M.A.; Waluya, S.B.; Junaedi I. (2017). Mathematical Creative Process Wallas Model in Students Problem Posing with Lesson Study Approach. International Journal of Instruction, 11(2), 527-538.

PISA. (2016). Result in Focus. Retrived 27 November, 2017 from https://www.oecd.org/pisa/pisa-2015-results-in-focus.pdf

Putra, G.N.Y.M.; Suweken, G.; Suarsana, I. M. (2016). Pengaruh Penggunaan ELearning Berbasis Edmodo Terhadap Prestasi Belajar Matematika Siswa Kelas X Paket Keahlian Teknik Gambar Bangunan SMK Negeri 3 Singaraja. Jurnal Pendidikan Matematika UNDIKSHA. 5/2.

Polya, G. (1954). How To Solve It. USA: Princeton University Press.

Roli, R., Mary M.C. \&Robert M.C. (2014). The Effect of Problem Posing on Student Mathematical Learning: A Meta-Analysis. International Education Studies, 7(13), $227-$ 241 .

Silver, E. (1994). On Mathematical Problem Posing. For the Learning of Mathematics, 14/1, 19-28.

Silver, E. \& Cai, J. (1996). An Analysis of Aritmatic Problem Posing by Middle School Students. Journal for Research in Mathematis Education, 27(5), 19-27.

Suherman, E. (2003). Strategi Pembelajaran Matematika Kontemporer. Bandung: Universitas Pendidikan Indonesia.

Sulisworo, D. \& Permprayon, K. (2018). What is the Better Social Media for Mathematics Learning ? A Case Study at A Rural School in Yogyakarta, Indonesia. International Journal on Emerging Mathematics Education, 2(1), 39-48.

Susanti, E.L, Sukestiyarno, YL, \& Sugiharti, E. (2012). Efektivitas Pembelajaran Matematika dengan Metode Problem Posing Berbasis Pendidikan Karakter. Unnes Journal of Mathematics Education.

Zarkasyi, W. (2015). Penelitian Pendidikan Matematika. Bandung: Refika Aditama. 